\title{
Enhancing Preschooler's Gross Motoric Using Pocket Book-Flipbook Maker Based
}

\author{
Wulan Patria Saroinsong ${ }^{1}$, Intan Kurnianingtyas ${ }^{1}$, Nurhenti Dorlina ${ }^{1,}$ Eka Cahya \\ Maulidiyah ${ }^{1}$ \\ Pendidikan Guru Pendidikan Anak Usia Dini, Universitas Negeri Surabaya, Indonesia(1) \\ DOI: $10.31004 /$ obsesi.v6i4.1556
}

\begin{abstract}
The urgency of study was overcome the lack of gross motor skill in young learners especially during pandemic Covid-19 which is entile online. This study emphasized to elaborate the development, feasibility and effectiveness of the flipbook maker-based concern on children's gross motor conducted to Indonesian traditional games. This study was conducted to research and development through ASSURE model. The target participant was involved the parents of children in 5-6 years old in Surabaya through online survey instruction to fill the google form regarding their children's gross motoric development since using the pocket book- flipbook maker. Eventually, this study revealed that the the pocket book- flipbook maker had effective than conventional media (Worksheet) to stimulate the children's gross motor skills. Furthermore, this study is expected to be able to contribute in early childhood education and technology in particular to enhancing children's gross motor skills during pandemic Covid19.
\end{abstract}

Keywords: gross motoric; pocket book; traditional games; flipbook maker.

\begin{abstract}
Abstrak
Urgensi pembelajaran tersebut untuk mengatasi kurangnya keterampilan motorik kasar pada peserta didik usia dini khususnya pada masa pandemi Covid-19 yang melibatkan aktivitas online. Penelitian ini ditekankan untuk mengelaborasi pengembangan, kelayakan dan keefektifan kepedulian berbasis flipbook terhadap motorik kasar anak yang dilakukan terhadap permainan tradisional Indonesia. Penelitian ini dilakukan dengan penelitian dan pengembangan melalui model ASSURE. Sasaran peserta adalah orang tua dari anak usia 5-6 tahun di Surabaya melalui instruksi survey online untuk mengisi google form tentang perkembangan motorik kasar anak sejak menggunakan pocket book-flipbook maker. Pada akhirnya, penelitian ini mengungkapkan bahwa pembuat flipbook buku saku lebih efektif daripada media konvensional (Lembar Kerja) untuk merangsang motorik kasar anak. Lebih lanjut, penelitian ini diharapkan dapat memberikan kontribusi dalam pendidikan anak usia dini dan teknologi khususnya untuk meningkatkan kemampuan motorik kasar anak di masa pandemi Covid-19.
\end{abstract}

Kata Kunci: motorik kasar; buku saku; permainan tradisional; flipbook maker.

Copyright (c) 2022 Wulan Patria Saroinsong, et al.

$\triangle$ Corresponding author :

Email Address : wulansaroinsong@unesa.ac.id (Surabaya, Indonesia)

Received 16 June 2021, Accepted 5 July 2021, Published 4 February 2022 


\section{INTRODUCTION}

The young Learners traits have different levels of each aspect. According to Saroinsong et al. (2020) ECE is a form of education that focuses on growth and six aspects of development namely religion and morals, physical motor, cognitive, language, social and art. In the meantime (Achmadi \& Lailiyyah, 2018), examined teachers do not stimulate gross motor skills, so many children are not able to coordinate their body movements optimally. Thus, it is necessary for the teacher's attention to pay attention to stimuli to support the gross motor development of students.

The preliminary study through 20 articles reviews in the early childhood journalgoogle scholar based linked the identification year 2015-2020, it was concluded that there was an influence of traditional games on gross motor skills in children. The research was conducted by Sudirman et al. (2019) Physical motor development can be improved through traditional games with the acquisition of a statistical test of 0.000 for children's motor development and 1.556 average difference values from the average before and after being given traditional games with a standard deviation of 1.097 from before and after being given the game traditional. It can be concluded that there is a significant influence between traditional games on motor development in children.

It Supported by Mu'mala \& Nadlifah, (2019); Adpriyadi, 2018) which found that traditional jumping rope games were able to optimize children's gross motor skills. The recent study has revealed that traditional games has been increasing gross motor skills. In the early act, it increased from $45.8 \%$ in the poor category, increased to $62.5 \%$ in the sufficient category in the first cycle, more over in further stage has increased to $77.08 \%$ in the good category of the second cycle, and became $95,83 \%$ with good category of third cycle. Meanwhile, (Van et al., 2019) examined thatT the gross motor skills of children are a strong factor in determining their lifelong activities. (Hestbaek et al., 2017) stated that preschool age determines the development of motor skills and may be an appropriate time to provide prevention strategies based on improving motor skills. While in some schools teachers have not been able to optimize gross motor skills in children. Moreover, in online learning like this, teachers become constrained in monitoring the developmental problems experienced by children.

As'ari \& Simatupang (2017) argue that gross motor skills are movements that involve large muscles in the body. This is in line with the opinion of (Santrock, 2007) which defines gross motor skills as skills possessed by a person including large muscle activities such as moving arms and walking. Ailwood (2003) states that play is an activity that young children can use to learn about how to be human according to Montessori or how to develop intellectually and socially. According to Vygotsky et al in (Andriani, 2012) suggests that games support growth and development, including cognitive development, social, language, physical motor and letter recognition. Sriwidayati et al. (2020) Playing games is an activity that is unique and different from other activities such as work or study, because work and study are carried out with the aim of achieving goals. When playing games children use their body muscles to stimulate their senses to explore their surroundings. One example of a game that affects children's gross motor skills is a traditional game. According to Apriliawati \& Hartoto (2016), traditional games are games that are created and played from generation to generation, which in the game do not have specific rules but contain the values of democracy, education, personality, health and unity. In other hand, children do not have physical motor skills, so the child does not feel confident in carrying out activities that involve physical activity. Good motor skills will help coordinate the movement of the child's body (Adpriyadi, 2018). In a previous study Munawaroh (2017), it was proven that using traditional engklek games was effective for stimulating early childhood development. Moreover, (Sulistyaningtyas \& Fauziah, 2019), proving that manuals are effective in optimizing gross motor skills in children.

The preliminary study had observed in children 5-6 years old at Kedungwilut Dharma 
Wanita Kindergarten (Taman Kanak-Kanak Dharma Wanita Kedungwilut), it examined that children have problems with their gross motor skills in terms of maintaining the balance of the child's body. In the meantime, the interview with teachers at the DW Kedungwilut Kindergarten are that during the COVID-19 pandemic, the teacher did not provide material in the form of gross motor activities directly, only the teacher gave children's worksheets (LKA) in the form of pictures illustrating gross motor activities and then only asked to colored the pictures.

The evidence has proven the non-optimalized of gross motor skills of children in the DW Kedungwilut Kindergarten due to the learning provided by the teacher is less varied. In addition, what affects is learning that is carried out online due to the current COVID-19 pandemic. Teachers become less understanding of the shortcomings experienced by each of their students. Learning that is done online makes children less interested in being active in participating in their learning. In this situation, it is necessary to develop the learning media. With the aim of children being more interested and able to overcome developmental problems, especially gross motor skills that occur in children.

In addition, it also supports online learning during the COVID-19 pandemic. The goal is that children can still optimize their gross motor skills even with online learning. According to John Dewey in (Preeti, 2014) education cannot be limited by teachers and the environment, therefore the researchers raised the topic of a flipbook maker-based gross motor pocket book for children to optimize the gross abilities of children aged 5-6 years.

In this flipbook maker-based gross motor pocket book, the researcher develops a pocket book into an e-book in which there are stages of activities to play traditional games of jumping rope and crank and video playing traditional games. The reason the researchers chose to use the traditional games of jumping rope and crank is because in the activities of jumping rope and ankle games, children use jumping activities. In this jumping activity, it can stimulate gross motor skills, especially in maintaining the coordination of the child's body balance. The purpose of this study was to determine the process of developing a flipbook maker-based gross motor activity pocket book, to determine the feasibility of a flipbook maker-based gross motor activity pocket book and to determine the results of the effectiveness test of a flipbook maker-based gross motor activity pocket book.

The urgency of this research is to implement a flipbook maker-based gross motor pocket book at TK DW Kedungwilut, Bandung District, Tulungagung Regency. This research is expected to be able to contribute to the optimization of gross motor skills and teacher learning media during the COVID-19 pandemic.

\section{METHODS}

This study was conducted to R\&D (Research and Development) though the ASSURE model. According to Rahmah (2016); Sugiono (2019) the ASSURE model is a learning design model that utilizes well-designed media and teaching materials, which makes students learn with enthusiasm and creates effective, efficient and interesting learning (Figure 1).

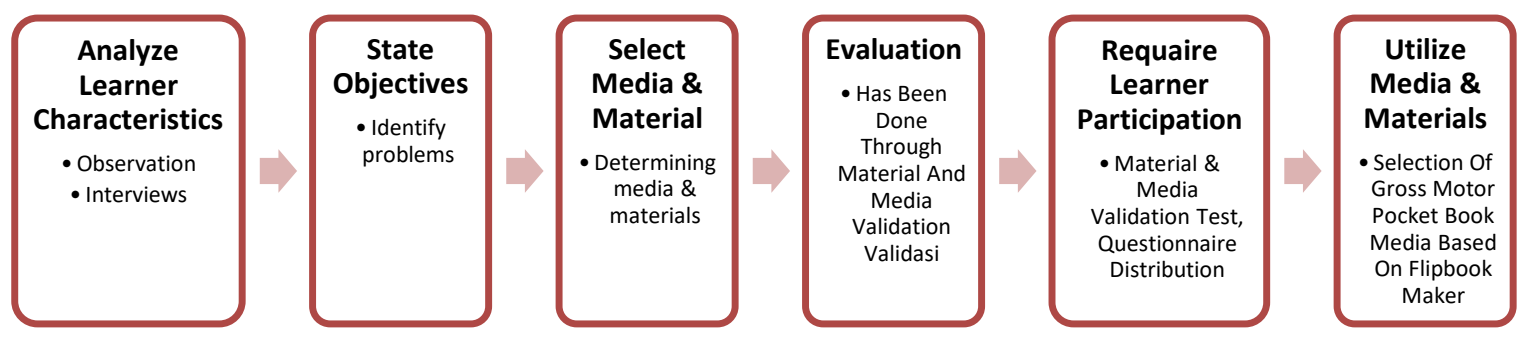

Figure 1. ASSURE Research Stages according to Smaldino in Fitrianingsih et al. (2019). 
Regarding the purpose of study design, it has been developed a pocket book-flipbook maker-based in particular to enhance children's gross motor during the COVID-19 pandemic. The target participants conducting parent of children 5-6 years old through purposive sampling with the criterias such as school accredited at least $B$, applying conventional learning such as LKA and question and answer. The implementation of the product (pocket bookflipbook maker-based) was disseminate at three kindergartens in Surabaya namely TK DW Ngunggahan 1, TK DW Kedungwilut, and Tk DW Bantengan. The procedure of the pilot study begins from TK DW Ngunggahan 1 as the school to the instrument of product trial. Once the product validated, the procedure had process to next the stage.

On this stage, this study conducted to the comparison approached using two schools as the target samples. As the target school of disseminating product, TK DW Kedungwilut has chosen as school sample to tried the gross motoric-flipbook maker-based, in the meantime TK DW Bantengan tried the conventional media (LKA).

Regardless the validly analysis, pearson correlation-product moment used to obtained the level of validity of survey items, in the meantime alpha cronbach used to find out the level of reliability. Moreover, descriptive statistical analysis and regression analysis aims to get an effectiveness of the flipbook maker-based in young children. Meanwhile, the feasibility test was carried out through one shoot stage, namely the media and material feasibility test on a flipbook maker-based gross motor pocket book conducted by experts judgement.

Explore the validity test for each item on parental perception regarding gross motor skills of children aged 5-6 years were declared valid or none of the question items fell out. In the calculation of the validity test using IBM SPSS V.22 with a sig level of 0.05 with the results of $r$ arithmetic above (0.51) on each question item, it is declared valid because $r$ table $>r$ count. This study uses the Cronbach's Alpha formula in the reliability test. the results on the questionnaire of parents' perceptions of children's gross motor skills were (0.876), then for the parents' questionnaire on the use of flipbook maker-based gross motor pocket book media (0.783). This means that the value of the coefficient of parental perception of children's gross motor skills and gross motor pocket media is above 0.6. Eventually, we have concluded that both questionnaires proved valid and reliable. The effectiveness gross motor-flipbook maker based, we analyze through descriptive statistics and its confirmed.

The feasibility of the gross motor pocket book based on the fipbook maker is proven by the expert judgment of Early Childhood Department, Jakarta University (ECE of UNJ). Moreover, the feasibility of the media confirmed by the expert judgment of technology curriculum, UNESA. The judgment confirmed that the acquisition of the media has the mean score (3.6) which is keen to a score of 4 which shows a range of 76-100, It was revealed that the media very effective therefore can apply to the target participants.

Table 1. Validity and Reliability Item

\begin{tabular}{ccccc}
\hline Items & $\begin{array}{c}\text { Pearson } \\
\text { Correlation }\end{array}$ & Sig. & $\begin{array}{c}\text { Cronbach's } \\
\text { Alpha }\end{array}$ & N of Items \\
\hline X1 & .612 & .015 & & \\
X2 & .833 & .000 & & \\
X3 & .614 & .015 & & \\
X4 & .739 & .002 & & \\
X5 & .625 & .013 & .876 & \\
X6 & .667 & .007 & & \\
X7 & .736 & .002 & & \\
X8 & .696 & .004 & & \\
X9 & .693 & .004 & & \\
X10 & .667 & .007 & & \\
\hline
\end{tabular}

Table 2. Rubric of Gross Motor-Flipbook Maker Based through Feasibility Test 


\begin{tabular}{ccc}
\hline Score & Range & Information \\
\hline 1 & $0-25$ & Very ineffective \\
2 & $26-50$ & Ineffective \\
3 & $51-75$ & Effective \\
4 & $76-100$ & Very effective \\
\hline
\end{tabular}

Table 3. Mean and Standard Deviation Gross Motor Handbook

\begin{tabular}{cccc}
\hline \multicolumn{4}{c}{ Gross Motor Handbook Feasibility Test } \\
\hline Aspect & Mean & Std. Deviation & Effectiveness Score \\
Theory & 3.6 & 0.51 & 4 \\
Media & 3.1 & 0.31 & 3 \\
\hline
\end{tabular}

(source: IBM SPSS V.22 data output)

Regardless the acquisition of material validation test scores, it was revealed a mean score (3.1) which is slightly keen to a score of 3 which shows a range of 51-75 (shown table 3). It was revealed that the media very effective therefore can apply to the target participants.. We can conclude it that the flipbook maker-based gross motor pocket book media is feasible to conducted on children.

\section{RESULTS AND DISCUSSION}

The stages of the process of developing a gross motor pocket book based on this flipbook maker, the first of which is the researcher analyzing the problems that exist in the school. The problems found by researchers include children's gross motor skills, especially in maintaining body balance. Then, researchers look for solutions to problems that have been found at the analysis stage. The solution found by the researchers was to use a flipbook makerbased gross motor pocket book educational media which was specifically designed to optimize children's gross motor skills. In addition, this media is suitable for use as learning media in schools and supports online learning media during the COVID-19 pandemic to optimize gross motor skills in children aged 5-6 years. Here is a link to access flipbok maker-based pocket book media; https://online.fliphtml5.com/uwfnm/nubq/.

The effectiveness of the flipbook maker-based gross motor pocket book on the gross motor skills of children aged 5-6 can be seen from the results of the descriptive test of the distribution of parents on the gross motor skills of children conducted by filling out an online survey on the google form, along with the rubik used;

Table 4. Scoring Rubric Descriptive Tes

\begin{tabular}{ccc}
\hline Score & $\begin{array}{c}\text { Scoring Rubric } \\
\text { Range }\end{array}$ & $\begin{array}{c}\text { Descriptive Test } \\
\text { Information }\end{array}$ \\
\hline 1 & $0-10$ & Undeveloped \\
2 & $11-20$ & Start Growing \\
3 & $21-30$ & Growing As Expected \\
4 & $31-40$ & Very Well Developed \\
\hline
\end{tabular}

Table 4 which contains the rubric is used as a reference to get the differenceof media between conventional media (LKA) and digital media (gross motor-flipbook maker based), we analyze through descriptive statistics and its confirmed.

The first finding admitted that children able to growth using the digital (Gross MotorFlipbook Maker Based). Table 5 shows a mean score (3.55) keen to a score of 4 (see table 4) which shows a range of 31-40 meaning that the balance item on children's gross motor skills on the flipbook maker-based gross motor pocket book media develops very well. Whereas in conventional media the balance item shows a mean value of 3.04 approaching the number 3 
which shows a range of 21-30, meaning that the balance item on children's gross motor skills for conventional media develops as expected.

The throwing item on the gross motor pocket book media shows a mean score of 3.00, indicating a score of 3 which shows a range of 21-30 meaning that the throwing item on gross motor skills for the flipbook maker-based gross motor pocket book media develops as expected. While throwing items on conventional media showed a mean value of 2.06, approaching a score of 2 which showed a range of 11-20, meaning that throwing items on children's gross motor skills for conventional media began to develop.

Table 5. Mean And Standard Deviation of Differences of Media Between Conventional Media (LKA) And Digital Media (Gross Motor-Flipbook Maker Based),

\begin{tabular}{ccccccc}
\hline Items & Mean & $\begin{array}{c}\text { Std. } \\
\text { Deviation }\end{array}$ & $\begin{array}{c}\text { Effectiveness } \\
\text { Score }\end{array}$ & Mean & $\begin{array}{c}\text { Std. } \\
\text { Deviation }\end{array}$ & $\begin{array}{c}\text { Effectiveness } \\
\text { Score }\end{array}$ \\
\hline Balance & 3.55 & 0.51 & 4 & 3.04 & 0.69 & 3 \\
\hline Throw & 3.00 & 0.84 & 3 & 2.06 & 0.50 & 2 \\
\hline Swing & 3.80 & 0.41 & 4 & 3.26 & 0.45 & 3 \\
\hline \multicolumn{7}{c}{ (source: IBM SPSS V.22 data output) }
\end{tabular}

While the item swinging on the gross motor pocket book media shows a mean value of 3.80 approaching a score of 4 which shows a range of 31-40 meaning that the throwing item on children's gross motor skills for the flipbook maker-based gross motor pocket book media develops very well. While the item swinging on conventional media shows a mean value of 3.26 approaching a score of 3 which shows a range of 21-30, meaning that the throwing item on children's gross motor skills on conventional media develops as expected.

In this study, the researchers used a flipbook maker-based gross motor pocket book as a treatment group variable and conventional media or LKA given by the school as a control group. In multiple regression analysis, it will be known whether or not there is an influence between the two media on the gross motor skills of children aged 5-6 years. The following are (table 6) the results of the analysis of multiple regression calculations.

According to (Mona et al., 2015) if the value of Sig. $<0.05$ then Ho is rejected and H1 is accepted. This means that there is an influence on the dependent variable. And if the value of Sig. $>0.05$ then Ho is accepted and H1 is rejected. This means that there is no effect on the dependent variable. In the table above that the value of (Sig.) X1 is $0.048<0.05$, then $\mathrm{H} 1$ is acceptable, which means that there is an influence on the gross motor pocket media based on flipbook maker on the gross motor skills of children aged 5-6 years. While the value (sig.) X2 is $0.858>0.05$ then $\mathrm{H} 2$ is not accepted, which means that there is no influence of conventional media or LKA on children's gross motor skills. So it can be concluded that the media of gross motor pocket book based on flipbook maker has an effect on gross motor skills in children.

Table 6. The Influence Two Media On The Gross Motor Skills Of Children Aged 5-6 Years

\begin{tabular}{cccc}
\hline variable & $\begin{array}{l}\text { Multiple Regression Test } \\
\text { Regression Efficiency }\end{array}$ & T count & Sig. \\
\hline Constant & 13.756 & & \\
X1 & .652 & 2.206 & .048 \\
X2 & -.057 & -.183 & .858 \\
\hline
\end{tabular}

(sumber : Output data IBM SPSS 22)

Note;

T table = 2.179; Y: Gross Motoric Children 5-6 years old; X1: Flipbook Maker-Based Gross Motors Pocket Book; X2: Conventional Media 
Confirmed by research conducted by (Munawaroh, 2017) using the traditional engklek game to be effective as a means of stimulating early childhood development. In line with the research conducted by (Anggraini et al., 2018) states that there is an influence and increase in playing jumping rope on children's gross motor development (jumping) so as to optimize all children's motor skills in the field of playing rubber playing jump rope for children aged 5-6 years.

However, for the comparison, the significance value is not too large, according to the researcher, this is due to the lack of gross motor stimulation provided by parents and teachers during learning at school. So this causes the child's gross motor skills to not develop perfectly. So the development of children in gross motor skills is very important to be given stimulation so that children's gross motor development develops optimally. In accordance with the statement put forward by (Ramdani \& Azizah, 2019), namely the importance of stimulating the gross motor skills of early childhood, so that their abilities develop optimally. Stimuli that can be given are providing physical activity and inviting children to exercise. The advantages of this flipbook maker-based rough pocketbook media can be accessed online and at any time and this media can be a learning medium that supports the optimization of gross motor skills during a pandemic or online learning. The disadvantage of the gross motor pocket book media based on flipbook makers is that to access it requires data or internet quota because this media cannot be accessed offline.

\section{CONCLUSION}

The urgency of this learning is to overcome the lack of gross motor skills in early childhood students, especially during the Covid-19 pandemic which involves online activities. Learning support media, especially to optimize children's gross motor skills, are needed during this COVID-19 pandemic. The results showed that the flipbook maker-based gross motor pocket book media was effective for optimizing the gross motor skills of children aged 5-6 years during online or online learning during the COVID-19 pandemic. This research is expected to contribute to the optimization of gross motor skills and teacher learning media during the COVID-19 pandemic.

\section{Acknowledgement}

Thank you to all parties involved in the process of making this scientific article. As well as to the editorial team of the obsession journal who has provided input to improve the quality of this article.

\section{REFERENCES}

A Sudirman, A., Modjo, D., \& Kalsum, U. (2019). Efektifitas Permainan Tradisionalterhadap Perkembangan Motorik Anak Usia Prasekolah. 215-224. https://doi.org/10.32528/psn.v0i0.1749

Achmadi \& Lailiyyah, L. (2018). Pengaruh Permainan Lompat Tali Terhadap Kemampuan Motorik Kasar Anak Kelompok B Tk Kartika Iv-9 Raider Surabaya. Wahana, 70(1), 6370. https://doi.org/10.36456/wahana.v70i1.1570

Adpriyadi, A. (2018). Permainan Tradisional Engklek untuk Meningkatkan Kemampuan Motorik Kasar Kelompok B. JPPM (Jurnal Pendidikan Dan Pemberdayaan Masyarakat), 4(2), 187-198. https://doi.org/10.21831/jppm.v4i2.10016

Ailwood, J. O. (2003). Governing Early Childhood. Contemporary Issues in Early Childhood, 4(3), 286- 299. https:// doi.org/10.2304/ciec.2003.4.3.5

Andriani, T. (2012). Permainan Tradisional Dalam Membentuk Karakter Anak Usia Dini. Jurnal Sosial Budaya, 9(1), 121-136. 
Anggraini, M. A., Karyanto, Y., \& A.S, W. K. (2018). Pengaruh Permainan Tradisional Lompat Tali terhadap Perkembangan Motorik Kasar Anak Usia 5-6 Tahun. Journal of Early Childhood Care and Education, 1(1), 18. https:// doi.org/10.26555/jecce.v1i1.60

Apriliawati, A. T \& Hartoto, S. (2016). Penerapan Permainan Tradisional Dalam Pembelajaran Pendidikan. Jurnal Pendidikan Olahraga Dan Kesehatan, 04, 522-528.

Ardisal. (2019). Efektitivitas Permaianan Lompat Tali Karet Untuk Meningkatkan Kemampuan Motorik Kasar Pada anak Tunagrahita Ringan. Journal of Special Education, 4(2), 137-146. https://doi.org/10.51529/ijiece.v4i2.164

As'ari, R. H dan Simatupang, N. D. (2017). Pengaruh Tari Kreasi " Penggembala Sapi" Terhadap Kemampuan Fisik Motorik Anak Kelompok B. Jurnal PAUD Teratai, Vol (06) No (03) .

Haryati, S. (2012). Research and Development (R\&D) Sebagai Salah Satu Model Penelitian dalam Bidang Pendidikan. Research And Development (R\&D) Sebagai Salah Satu Model Penelitian Dalam Bidang Pendidikan, 37(1), 11-26.

Hestbaek, L., Andersen, S. T., Skovgaard, T., Olesen, L. G., Elmose, M., Bleses, D., Andersen, S. C., \& Lauridsen, H. H. (2017). Influence of motor skills training on children's development evaluated in the Motor skills in PreSchool (MiPS) study-DK: Study protocol for a randomized controlled trial, nested in a cohort study. Trials, 18(1), 1-11. https:/ / doi.org/10.1186/s13063-017-2143-9

Hidayanti, M. (2013). Peningkatan Kemampuan Motorik Kasar Anak Melalui Permainan Bakiak. Pendiidkan Anak Usia Dini, 7(1), 195-200

John W. Satrock (2017). Perkembangan Anak. Jilid 1 Edisi kesebelas. Jakarta: PT. Erlangga.

Maulidiyah, E. C. (2017). Asessment Perkembangan Motorik Kasar Anak Usia 4-5 Tahun. Martabat: jurnal Perempuan dan anak: Vol. vol 1 no 1 (p. 20). https:// doi.org/10.21274/martabat.2017.1.1.45-64

Mona, M., Kekenusa, J., \& Prang, J. (2015). Penggunaan Regresi Linear Berganda untuk Menganalisis Pendapatan Petani Kelapa. Studi Kasus: Petani Kelapa Di Desa Beo, Kecamatan Beo Kabupaten Talaud. D'CARTESIAN, 4(2), 196. https:// doi.org/10.35799/dc.4.2.2015.9211

Mu'mala, K. A dan Nadlifah. (2019). Optimalisasi Permainan Lompat Tali dalam Mengembangkan Motorik Kasar Anak Khuri Abad Mu'mala, Nadlifah | 57. Jurnal Ilmiah Tumbuh Kembang Anak Usia Dini, 4(1), 57-68. https:// doi.org/10.14421/iga.2019.41-06

Munawaroh, H. (2017). Pengembangan Model Pembelajaran dengan Permainan Tradisional Engklek Sebagai Sarana Stimulasi Perkembangan Anak Usia Dini. Jurnal Obsesi : Jurnal Pendidikan Anak Usia Dini, 1(2), 86. https://doi.org/10.31004/obsesi.v1i2.19

Nasrullah, A. C \& Reza, M. (2020). Pengembangan Buku Panduan Kegiatan Pembelajaran Mitigasi Bencana Kebakaran Pada Anak Usia 5-6 Tahun. PAUD Teratai, 09(01), 1-12. https://jurnalmahasiswa.unesa.ac.id/index.php/paud-teratai/article/view/34329

Preeti. (2014). Education and role of media in education system. International Journal of $\begin{array}{llll}\text { Scientific Engineering } & \text { 174-175. }\end{array}$ http://www.ijser.in/archives/v2i3/SjIwMTMxNTg=.pdf

Rahmah, N. (2016). "Pengembangan Media Pembelajaran Interaktif Berbasis Assure Pokok Bahasan Virus Kelas X Sma Negeri 11 Makassar." Journal of Chemical Information and Modeling, 35-36. 
DOI: 10.31004/obsesi.v6i4.1556

Ramdani, L. A., \& Azizah, N. (2019). Permainan Outbound untuk Perkembangan Motorik Kasar Anak Usia Dini. Jurnal Obsesi : Jurnal Pendidikan Anak Usia Dini, 4(1), 494. https://doi.org/10.31004/obsesi.v4i1.407

Saroinsong, W.P, Farikhah, W. A, \& Widayati, S. (2020). Media Buku Saku Berbasis Motorik Halus Untuk Anak Pra-Sekolah. 4(1), 67-83. https:// doi.org/10.35896/ijecie.v4i1.106

Sriwidayati, Saroinsong, W. P., \& Simatupang, N. (2020). Traditional Games Usage to Improve the Children's Independence Skill. 454(Ecep 2019), 240-244. https://doi.org/10.2991/assehr.k.200808.047

Sugiyono. (2019). Metode penelitian pndidikan. Bandung: CV Alfabeta

Sulistyaningtyas, R. E., \& Fauziah, P. Y. (2019). Pengembangan buku panduan permainan tradisional untuk meningkatkan kemampuan motorik kasar anak usia 5-6 tahun. JPPM (Jurnal Pendidikan Dan Pemberdayaan Masyarakat), 6(1), 50-58. https://doi.org/10.21831/jppm.v6i1.23477

Van Der Fels, I. M. J., Smith, J., De Bruijn, A. G. M., Bosker, R. J., Königs, M., Oosterlaan, J., Visscher, C., \& Hartman, E. (2019). Relations between gross motor skills and executive functions, controlling for the role of information processing and lapses of attention in 8-10 year old children. PLoS ONE, 14(10), 1-16. https://doi.org/10.1371/journal.pone.0224219

Wiranti, D. A., \& Mawarti, D. A. (2018). Keefektiffan Permainan Engklek Dalam Mengembangkan Kemampuan Motorik Kasar Anak Usia Dini. Refleksi Edukatika: Jurnal Ilmiah Kependidikan, 9(1). https:// doi.org/10.24176/re.v9i1.2810 